\title{
Energy study of a non-residential and historic building in transient conditions
}

\author{
S. Grignaffini, M. Romagna \& A. Vallati \\ Department of Astronautical, Electrical and Energetic Engineering, \\ Sapienza, University of Rome, Italy
}

\begin{abstract}
The purpose of this manuscript is to analyse the interventions of energy retrofit of a non-residential and historic building, through dynamic simulation by the use of the TRNsys code. The study is made up of some steps:
\end{abstract}

- the analysis of the building and utility data, including study of the installed equipment and analysis of energy bills;

- the survey of the real operating conditions;

- the selection and the evaluation of energy conservation measures;

- the identification of interventions of energy retrofit;

- TRNsys simulation of the effects of these interventions on the energy behaviour of the building.

The present paper aims to present the results of the study, to discuss the expected energy behaviour of the building and to comment on the options for introducing energy conservation techniques.

Keywords: energy efficiency, retrofit solution, historical building, transient state calculation. 


\section{Introduction}

The case study building is the Headquarters of the National Italian Monopoly which regulates the production and sale of tobacco. The building is located in Rome and is composed of two parts (or two different buildings): the smaller building has a significant historical value as it dates back to the second half of the nineteenth century and the larger one dates back to the 60 s. For convenience the two buildings will be called respectively "historic building" and "modern building". The geometric characteristics of the two buildings and the ratio (shape ratio) between the heat loss surfaces (walls, windows, floors and thermal bridges) and volume $(\mathrm{S} / \mathrm{V})$ are shown in Table 1 :

Table 1: Geometrical characteristics of the buildings.

\begin{tabular}{|c|c|c|c|c|}
\hline & $\begin{array}{c}\text { Height } \\
(\mathrm{m})\end{array}$ & $\begin{array}{c}\text { Surface } \\
\left(\mathrm{m}^{2}\right)\end{array}$ & $\begin{array}{c}\text { Volume } \\
\left(\mathrm{m}^{3}\right)\end{array}$ & $\begin{array}{c}\mathrm{S} / \mathrm{V} \text { ratio } \\
\left(\mathrm{m}^{2} / \mathrm{m}^{3}\right)\end{array}$ \\
\hline Historic building & 22 & 1,030 & 20,000 & 0.29 \\
\hline Modern building & 24 & 3,040 & 70,300 & 0.28 \\
\hline
\end{tabular}

The two buildings (Figure 1) were built at different times so the thermal performance characteristics are significantly different. The "historic building" is a bearing masonry building and it's characterized by small glazing surfaces while the "modern building" is a reinforced concrete building and it's characterized by large glazing surfaces and cavity walls with small insulating layer. This characteristic is the main cause of the overheating in summer time. A precise evaluation of the contributions from solar radiation through the glazing surfaces is not easy because of the shadows made by the surrounding buildings. This manuscript, according to several case studies [1-3], will evaluate the effect of retrofit interventions on improving the energy efficiency of the building above in some steps:

- the analysis of the building and utility data, including study of the installed equipment and analysis of energy bills;

- the survey of the real operating conditions;

- the selection and the evaluation of energy conservation measures;

- the identification of interventions of energy upgrading;

- TRNsys simulation of the effects of these interventions on energy behavior of the building.

\section{Energy study of the building}

The study starts with the collection of data on energy consumption of the building (gas and electricity) including the study of the installed equipment, with the survey of all the elements of the building which are responsible for loss (winter time) and the accumulation (summer time) of heat and with the direct 
(a)

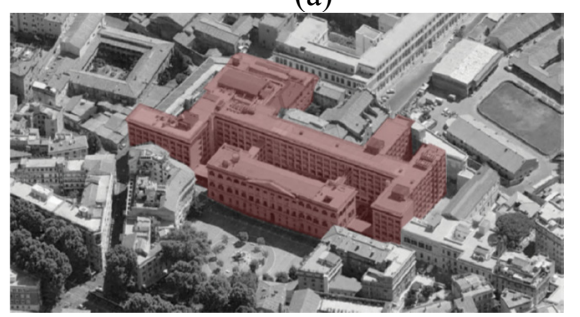

(b)

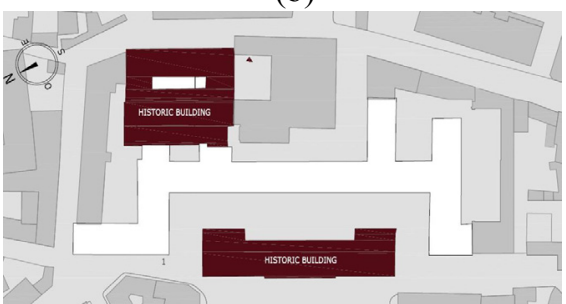

(c)

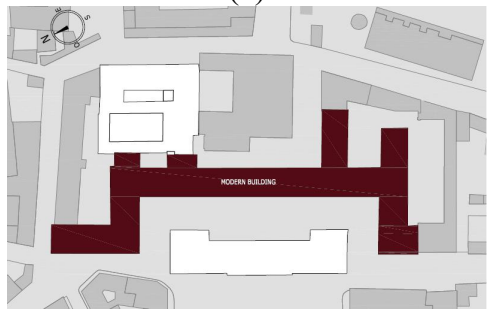

Figure 1: Case study: position in the urban context (a), historic building (b) and modern building (c).

(a)

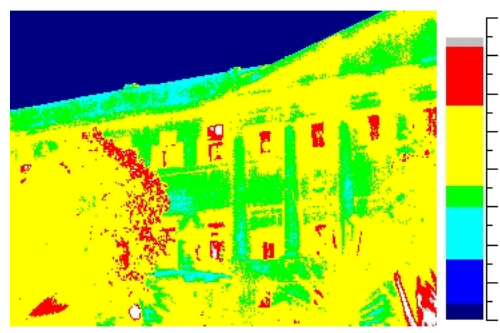

(b)

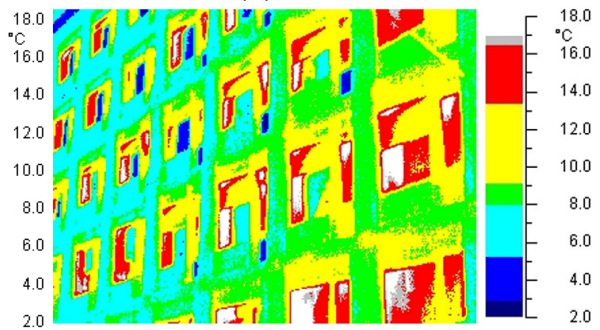

Figure 2: Thermographic survey: "historic building"(a) and "modern building" (b) main facades.

survey on energy performance (e.g. thermographic survey, Figure 2). A model of dynamic calculation with the TRNsys code will be calibrated through the data of this energy audit and the energy demand of the building in time will be known.

\subsection{Building construction characteristics}

The external walls (cavity walls) of the "modern building" are in air-bricks (thickness of $30 \mathrm{~cm}$ ) with a small layer of insulating material (polystyrene $2 \mathrm{~cm}$ ). The external walls of "historic building" are "stone walls" type and their 
thickness decrease with the height: the thickness is between $1 \mathrm{~m}$ and $0.8 \mathrm{~m}$ and there is no insulating layer.

\subsubsection{External walls}

The external walls (cavity walls) of the "modern building" are in air-bricks (thickness of $30 \mathrm{~cm}$ ) with a small layer of insulating material (polystyrene $2 \mathrm{~cm}$ ). The external walls of the "historic building" are of "stone walls" type and their thickness decreases with the height: the thickness is between $1 \mathrm{~m}$ and $0.8 \mathrm{~m}$ and there is no insulating layer.

\subsubsection{Glazing surfaces}

The "modern building" has a considerable percentage of glazing surfaces amounting to approximately $33 \%$ of each facade. They represent a large part of heat loss surfaces and affect significantly the thermal behavior of the building. All of that is confirmed by the thermographic survey (see Figure 2) and it's mostly due to the poor quality of glazing surfaces (simple single glass). The "Historic Building" has the same type of glazing surfaces but with less extension.

\subsection{Energy consumption, heating and cooling demands}

The energy audit starts with the calculation of the energy demand during the year, obtained by the analysis of energy bills (electricity and gas consumption) and by the analysis of the installed equipment. The heating demand, related to consumption of natural gas, was obtained by the following formula:

$$
\mathrm{E}=\mathrm{V}_{\text {gas }} \cdot \mathrm{P}_{\mathrm{c}} \cdot \eta_{\mathrm{t}}
$$

with $E[k J]$ the energy required in a given period of time when $V_{\text {gas }}\left[\mathrm{m}^{3}\right]$ of natural gas with calorific value $\left(\mathrm{P}_{\mathrm{c}}\right)$ equal to $34,541 \mathrm{~kJ} / \mathrm{m}^{3}$ are burned. The performance efficiency $\eta_{t}$ is given by the manufacturer's data sheets of the heating system. An analysis conceptually similar was followed for cooling demand, made by the data of electricity consumption: in this case the performance efficiency is given by the Coefficient of Performance (COP) of the cooling system. All the values are the sum of total consumption (cooling systems and lighting) and an extrapolation was necessary. Through this analysis, it was possible to obtain the Energy Performance index (EP) which represents the ratio between the yearly energy used for special purposes (e.g., heating, cooling, hot water and indoor lighting), and the volume of the building. Table 2 shows the values of energy demand and the Energy Performance indexes:

Table 2: Heating, hot water supply and cooling demands.

\begin{tabular}{|c|c|c|c|c|}
\hline Use & $\begin{array}{c}\text { Gas use } \\
\left(\mathrm{m}^{3} / \text { year }\right)\end{array}$ & $\begin{array}{c}\text { Electricity } \\
(\mathrm{kWh} / \text { year })\end{array}$ & $\begin{array}{c}\text { Energy } \\
(\mathrm{kWh} / \text { year })\end{array}$ & $\begin{array}{c}\text { EP } \\
\left(\mathrm{kWh} / \mathrm{m}^{3} \text { year }\right)\end{array}$ \\
\hline Heating & 167,557 & - & $1,543,361$ & 18.3 \\
\hline Hot water supply & 3,952 & - & 36,781 & 1.35 \\
\hline Cooling & - & 295,887 & 887,725 & 10.10 \\
\hline
\end{tabular}




\subsection{TRNsys model}

Figure 3 shows the TRNsys model of the building, calibrated by the data obtained from the energy audit, and improved in order to determinate infiltrations and thermal bridges and to verify the effects of shadows produced by surrounding building, the effects produced by the temperature of basements (not controlled temperature) and the effects produced by the fixed shielding of the windows on the top floor. The output results of the TRNsys solver can be analyzed in order to obtain the thermal behaviour of the building; Figure 4 represents the heating and cooling demands (heating and cooling powers) of the two buildings during the year. The peak intensities obtained from the calculation is about $4 \mathrm{MW}$ for heating and $2 \mathrm{MW}$ for cooling.

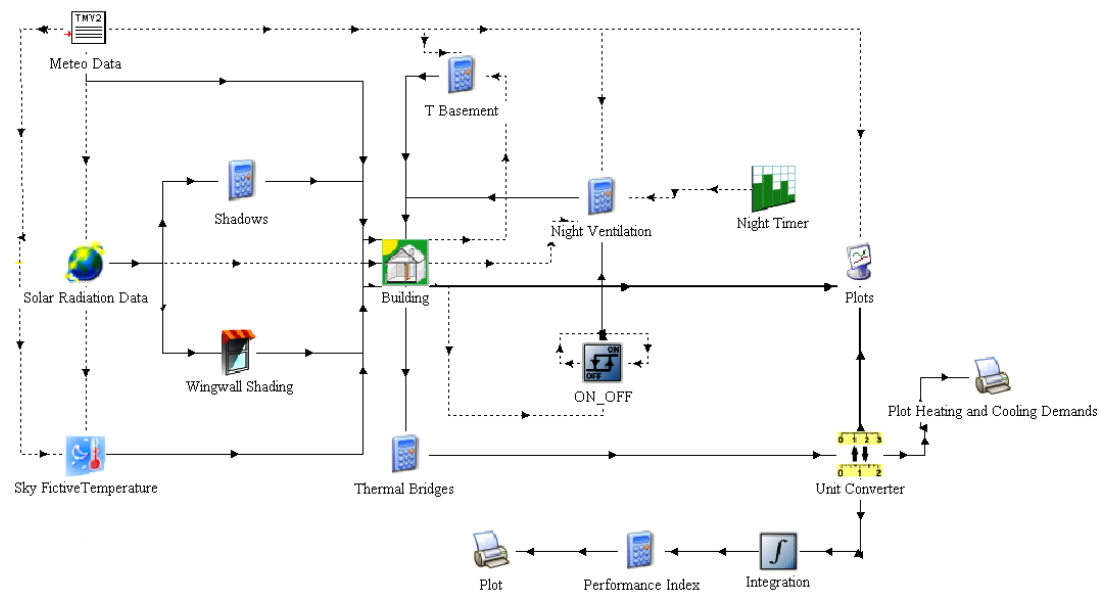

Figure 3: TRNsys model.

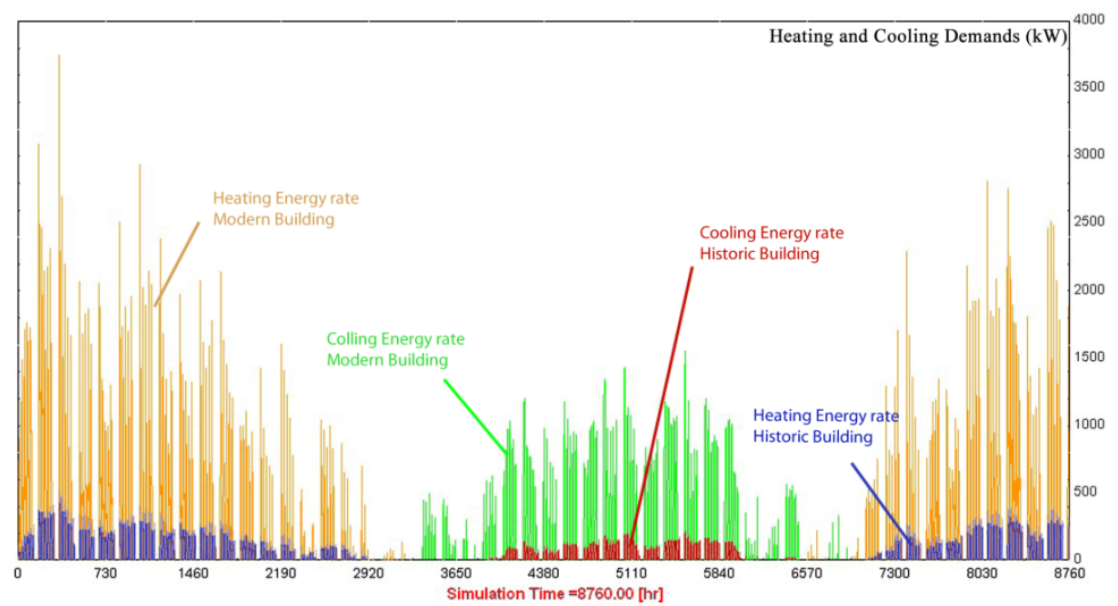

Figure 4: Yearly heating and cooling demands: TRNsys model outputs. 


\subsubsection{Temperatures}

Figure 5 reports the annual temperature trend of ground floor, basement and outdoor temperatures for the "modern building". The trend of outdoor temperature follows the statistical data in the database used (Meteonorm), while the temperature of the basement, bordering the ground floor, $\left(\mathrm{T}_{\mathrm{b}}\right)$, follows the equation:

$$
\mathrm{T}_{\mathrm{b}}=\mathrm{T}_{\mathrm{s}}+\frac{\left(\mathrm{T}_{\mathrm{a}}-\mathrm{T}_{\mathrm{s}}\right)}{6}+\frac{\left(\mathrm{T}_{\mathrm{i}}-\mathrm{T}_{\mathrm{s}}\right)}{3.5}
$$

obtained correlating the ambient temperature $T_{a}$, the soil temperature $T_{s}$ and the indoor temperature of ground floor $\mathrm{T}_{\mathrm{i}}$.

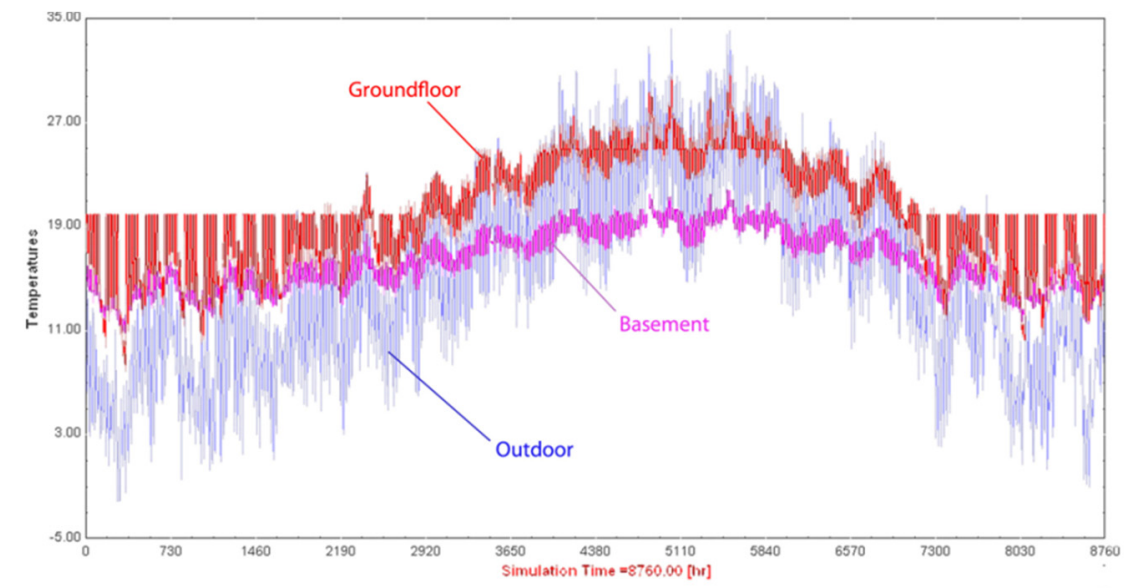

Figure 5: TRNsys model outputs: yearly temperature trend for basement and ground floor of "modern building".

The trend of temperatures shows considerable fluctuations in winter time and summer time due to the operation of the heating and cooling systems during working hours only, while, in spring time and autumn time, the temperature values belong to the required range in which there is no the need for heating and cooling systems. In Table 3, it is possible to summarize all the results obtained by TRNsys simulation about the heating and cooling demands and the Energy Performance Indexes:

\section{Energy retrofit solutions}

\subsection{Historic building}

\subsubsection{Transmittance of walls and floors}

Changes to the TRNsys model have been made, in order to consider the arrangement of different thickness of insulation on external walls and floors bordering with unheated spaces (rooftop and ground floor). 
Table 3: Main results obtained by the TRNsys simulation.

\begin{tabular}{|c|c|c|c|}
\hline & $\begin{array}{c}\text { Historic } \\
\text { building }\end{array}$ & $\begin{array}{c}\text { Modern } \\
\text { building }\end{array}$ & Global \\
\hline Heating $[\mathrm{kWh} /$ year $]$ & 290,730 & $1,238,500$ & $1,520,230$ \\
\hline Cooling $[\mathrm{kWh} /$ year $]$ & 82,950 & 572,700 & 655,650 \\
\hline $\mathrm{EP}_{\text {heat }}\left[\mathrm{kWh} / \mathrm{m}^{3}\right.$ year $]$ & 15.30 & 19.40 & 18.40 \\
\hline $\mathrm{EP}_{\text {cool }}\left[\mathrm{kWh} / \mathrm{m}^{3}\right.$ year $]$ & 4.50 & 9.00 & 8.20 \\
\hline
\end{tabular}

The proposed insulating material has a heat capacity $\left(\mathrm{c}_{\mathrm{p}}\right)$ of $1453 \mathrm{~J} / \mathrm{kg} \mathrm{K}$, a thermal conductivity $(\lambda)$ of $0.023 \mathrm{~W} / \mathrm{m} \mathrm{K}$ and a density $(\rho)$ of $36 \mathrm{~kg} / \mathrm{m}^{3}$. There are 6 different interventions proposed; each one has been compared with the calculation to the current situation in order to assess the effects. The results are different according to the arrangement of the insulation. The floors, thermally less efficient, affect significantly the global behavior. With these proposals, the total energy requirement can be reduced up to the $76 \%$ of the current value; a minimum intervention with a thickness of $2 \mathrm{~cm}$ insulation leads to a reduction of $86 \%$ of the current value. Furthermore, the thickness of insulation is not linearly related with the total needs but the benefit gradually decreases, so it will be important to evaluate these correlations on global investment.

\subsubsection{Transmittance of glazing surfaces}

Table 4 shows the characteristics of glazing surfaces, where $U$-value indicates the transmittance and G-value or Solar Factor, the ratio between the thermal energy globally transmitted from the glazing surface and the thermal energy incident upon it.

Table 4: Characteristics of glazing surfaces.

\begin{tabular}{|c|c|c|c|}
\hline & Thickness $[\mathrm{mm}]$ & U-value $\left(\mathrm{W} / \mathrm{m}^{2} \mathrm{~K}\right)$ & G-value \\
\hline Single & 4 & 5.68 & 0.855 \\
\hline Double & $4 / 16 / 4$ & 2.83 & 0.755 \\
\hline Krypton & $4 / 16 / 4$ & 0.81 & 0.633 \\
\hline
\end{tabular}

The choice to change the characteristics of the glazing surfaces could have few benefits; in fact, this type of intervention often has a high cost respect to a limited benefit. With the choice of glass with high performance, the energy demand reduction reaches $90 \%$ of the current value: this can be explained by the limited extension of glazing surfaces and their poor exposure caused by the shadows generated by surrounding buildings. All the results are reported in Table 5 and Figure 6.

\subsection{Modern building}

The same intervention is adopted in the case of the "modern building" which is totally different from the previous one by type and time of construction, size, percentage of glazing surfaces, etc. 
518 Energy and Sustainability VI

Table 5: "Historic building": effects of interventions on performance indexes.

\begin{tabular}{|c|c|c|c|}
\hline \multicolumn{4}{|c|}{ Windows replacing } \\
\hline & $\begin{array}{c}\mathrm{EP}_{\text {heat }} \\
{\left[\mathrm{kWh} / \mathrm{m}^{3} \text { year }\right]}\end{array}$ & $\begin{array}{c}\mathrm{EP}_{\text {cool }} \\
{\left[\mathrm{kWh} / \mathrm{m}^{3} \text { year }\right]}\end{array}$ & $\begin{array}{c}\mathrm{EP}_{\text {heat }}+\mathrm{EP}_{\text {cool }} \\
{\left[\mathrm{kWh} / \mathrm{m}^{3} \text { year }\right]}\end{array}$ \\
\hline Single (current) & 15.30 & 4.50 & 19.80 \\
\hline Double & 14.10 & 4.40 & 18.50 \\
\hline Krypton & 13.80 & 4.10 & 17.90 \\
\hline \multicolumn{4}{|c|}{ Insulation } \\
\hline Current & $\begin{array}{c}\mathrm{EP} \text { heat } \\
{\left[\mathrm{kWh} / \mathrm{m}^{3} \text { year }\right]}\end{array}$ & $\begin{array}{c}\mathrm{EP}_{\text {cool }} \\
{\left[\mathrm{kWh} / \mathrm{m}^{3} \text { year }\right]}\end{array}$ & $\begin{array}{c}\mathrm{EP} \text { heat } \\
{\left[\mathrm{kWh} / \mathrm{EP}^{3} \text { year }\right.}\end{array}$ \\
\hline 2 cm external walls & 15.30 & 4.50 & 19.80 \\
\hline 6 cm floors & 13.45 & 4.40 & 17.85 \\
\hline $2 \mathrm{~cm}$ external walls and floors & 12.65 & 4.60 & 17,60 \\
\hline $2 \mathrm{~cm}$ external walls +6 cm floors & 12.20 & 4.20 & 16.95 \\
\hline $4 \mathrm{~cm}$ external walls +6 cm floors & 11.50 & 4.00 & 16.40 \\
\hline $6 \mathrm{~cm}$ external walls and floors & 11.10 & 3.70 & 14.80 \\
\hline
\end{tabular}

(a)

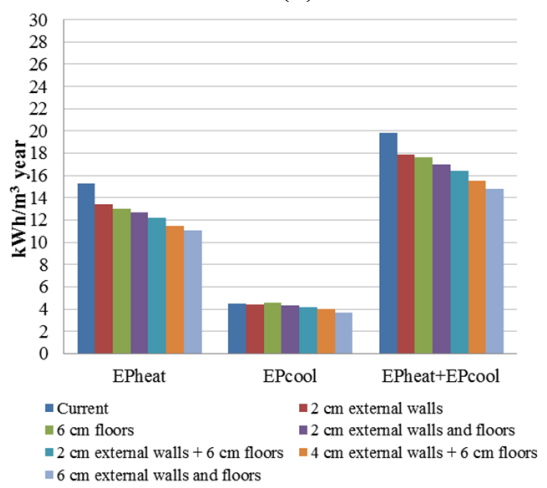

(b)

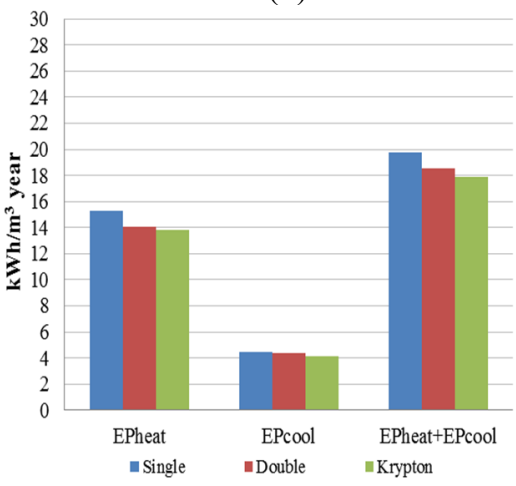

Figure 6: "Historic building": effects of interventions: (a) walls and floors and (b) glazing surfaces. 
(a)

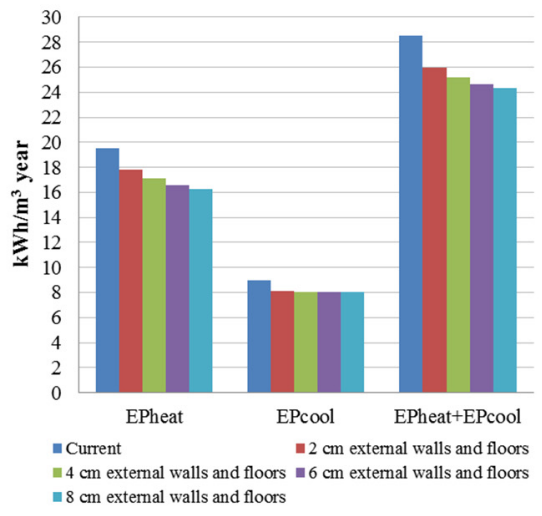

(b)

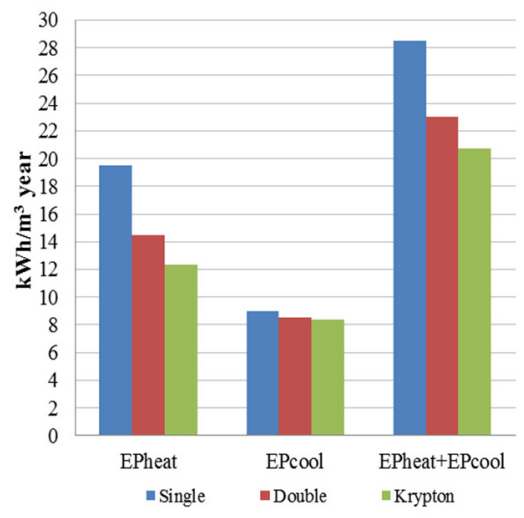

Figure 7: "Modern building": effects of interventions: (a) walls and floors and (b) glazing surfaces.

Table 6: "Modern building": effects of interventions on Performance Indexes.

\begin{tabular}{|c|c|c|c|}
\hline & $\begin{array}{c}\text { Windows replacing } \\
{\left[\mathrm{kWh} / \mathrm{m}^{3} \text { year }\right]}\end{array}$ & $\begin{array}{c}\mathrm{EP}_{\text {cool }} \\
{\left[\mathrm{kWh} / \mathrm{m}^{3} \text { year }\right]}\end{array}$ & $\begin{array}{c}\mathrm{EP}_{\text {heat }}+\mathrm{EP}_{\text {cool }} \\
{\left[\mathrm{kWh} / \mathrm{m}^{3} \text { year }\right]}\end{array}$ \\
\hline Single (current) & 19.50 & 9,00 & 28.50 \\
\hline Double & 14.47 & 8.55 & 23.02 \\
\hline Krypton & 12.35 & 8.40 & 20.75 \\
\hline \multicolumn{4}{|c|}{ Insulation } \\
\hline Current & $\begin{array}{c}\mathrm{EP} \text { heat } \\
{\left[\mathrm{kWh} / \mathrm{m}^{3} \text { year }\right]}\end{array}$ & $\begin{array}{c}\mathrm{EP}_{\text {cool }} \\
\left.\mathrm{kWh} / \mathrm{m}^{3} \text { year }\right]\end{array}$ & $\begin{array}{c}\mathrm{EP}_{\text {heat }}+\mathrm{EP}_{\text {cool }} \\
{\left[\mathrm{kWh}^{3} / \mathrm{m}^{3} \text { year }\right]}\end{array}$ \\
\hline $2 \mathrm{~cm}$ external walls and floors & 19.50 & 9.00 & 28.50 \\
\hline $4 \mathrm{~cm}$ external walls and floors & 17.84 & 8.09 & 25.93 \\
\hline $6 \mathrm{~cm}$ external walls and floors & 16.60 & 8.06 & 25.18 \\
\hline $8 \mathrm{~cm}$ external walls and floors & 16.25 & 8.07 & 24.65 \\
\hline
\end{tabular}

\section{Conclusions}

The retrofit interventions, selected on improving the energy efficiency of the building are listed below:

"Modern building":

- $\quad$ provision of an insulating layer of about $4 \mathrm{~cm}$ for the walls and of about $6 \mathrm{~cm}$ for the floors. (Heat capacity $700 \mathrm{~J} / \mathrm{kg} \mathrm{K}$, thermal conductivity $0.18 \mathrm{~kJ} / \mathrm{h} \mathrm{m} \mathrm{K}$, density $80 \mathrm{~kg} / \mathrm{m}^{3}$.) 
- replacement of single glazing windows (thickness $4 \mathrm{~mm}$, U-value $5.68 \mathrm{~W} / \mathrm{m}^{2} \mathrm{~K}$, G-value 0.855) with double glazing windows. (Thickness 416-4 mm, U-value $2.83 \mathrm{~W} / \mathrm{m} 2 \mathrm{~K}$, G-value 0.755 .)

"Historic building":

- $\quad$ provision of an insulating layer of about $4 \mathrm{~cm}$ for the walls and of about $6 \mathrm{~cm}$ for the floors.

Tables 7 and 8 show the results obtained while Figure 8 shows the heating and cooling demands of "modern building" after the interventions.

Table 7: "Modern and historic buildings": effects of interaction of interventions.

\begin{tabular}{|c|c|c|c|}
\hline & $\begin{array}{c}\text { Historic } \\
\text { Building }\end{array}$ & $\begin{array}{c}\text { Modern } \\
\text { Building }\end{array}$ & Global \\
\hline Heating $[\mathrm{kWh} /$ year $]$ & 243,100 & 608,000 & 851,100 \\
\hline Cooling $[\mathrm{kWh} /$ year $]$ & 75,800 & 550,200 & 626,000 \\
\hline $\mathrm{EP}_{\text {heat }}\left[\mathrm{kWh} / \mathrm{m}^{3}\right.$ year $]$ & 12.80 & 9.40 & 10.30 \\
\hline $\mathrm{EP}_{\text {cool }}\left[\mathrm{kWh} / \mathrm{m}^{3}\right.$ year $]$ & 4.00 & 8,60 & 7.50 \\
\hline
\end{tabular}

Table 8: "Modern and historic buildings": final report.

\begin{tabular}{|c|c|c|c|}
\hline & Initial Value & Final Value & Reduction [\%] \\
\hline Heating [kWh/year] & $1,529,230$ & 851,100 & -44.4 \\
\hline Cooling [kWh/year] & 655,650 & 626,000 & -4.5 \\
\hline $\mathrm{EP}_{\text {heat }}\left[\mathrm{kWh} / \mathrm{m}^{3}\right.$ year $]$ & 18.40 & 10.30 & \\
\hline $\mathrm{EP}_{\text {cool }}\left[\mathrm{kWh} / \mathrm{m}^{3}\right.$ year$]$ & 8.20 & 7.50 & \\
\hline
\end{tabular}

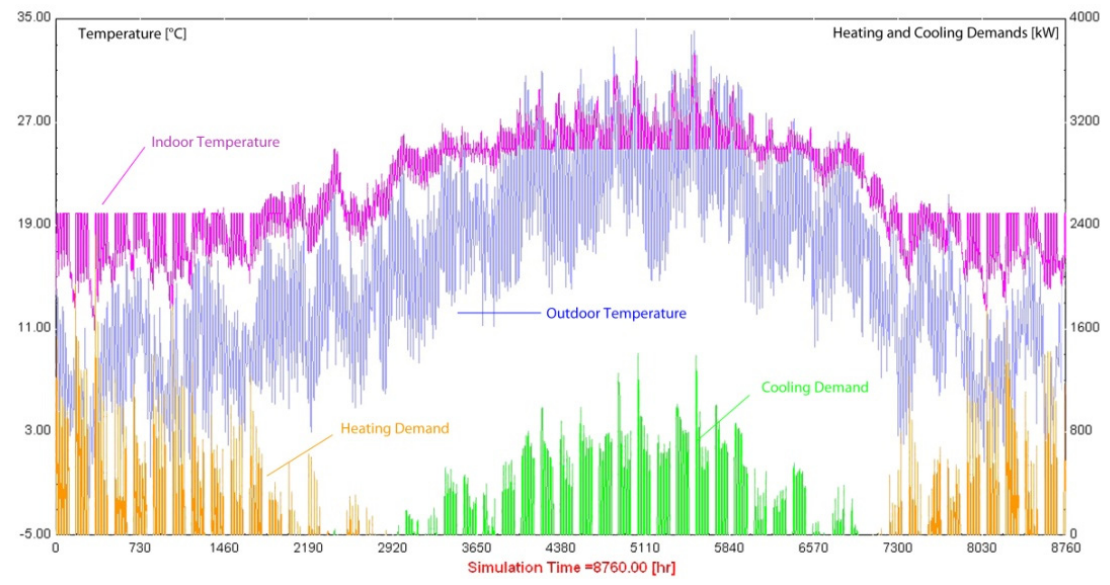

Figure 8: "Modern building": yearly heating and cooling demands after interventions. 


\section{References}

[1] Papadopoulos M.; Avgelis A.; Santamouris M., Energy Study of a Medieval Tower Restored as a Museum; Energy and Buildings, Vol. 35, No. 9, 2003, pp. 951-961. doi:10.1016/S0378-7788(03)00025-2.

[2] Perez-Lomnard L., et al., A Review on Buildings Energy Consumption Information; Journal Energy and Buildings, Vol. 40, No. 3, 2008, pp. 394398.

[3] Del Curto C.; Fratelli M., Historical Building as Museums: Building and Artworks Preservation; Plans for Existing System Restoration and Integration; Il Prato, Vicenza, 2010. 